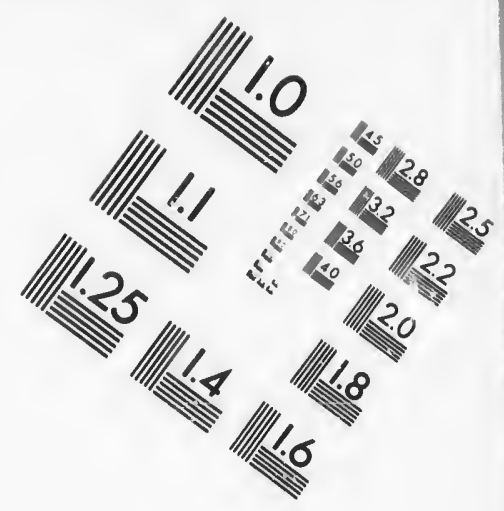

TEST TARGET (MT-3)
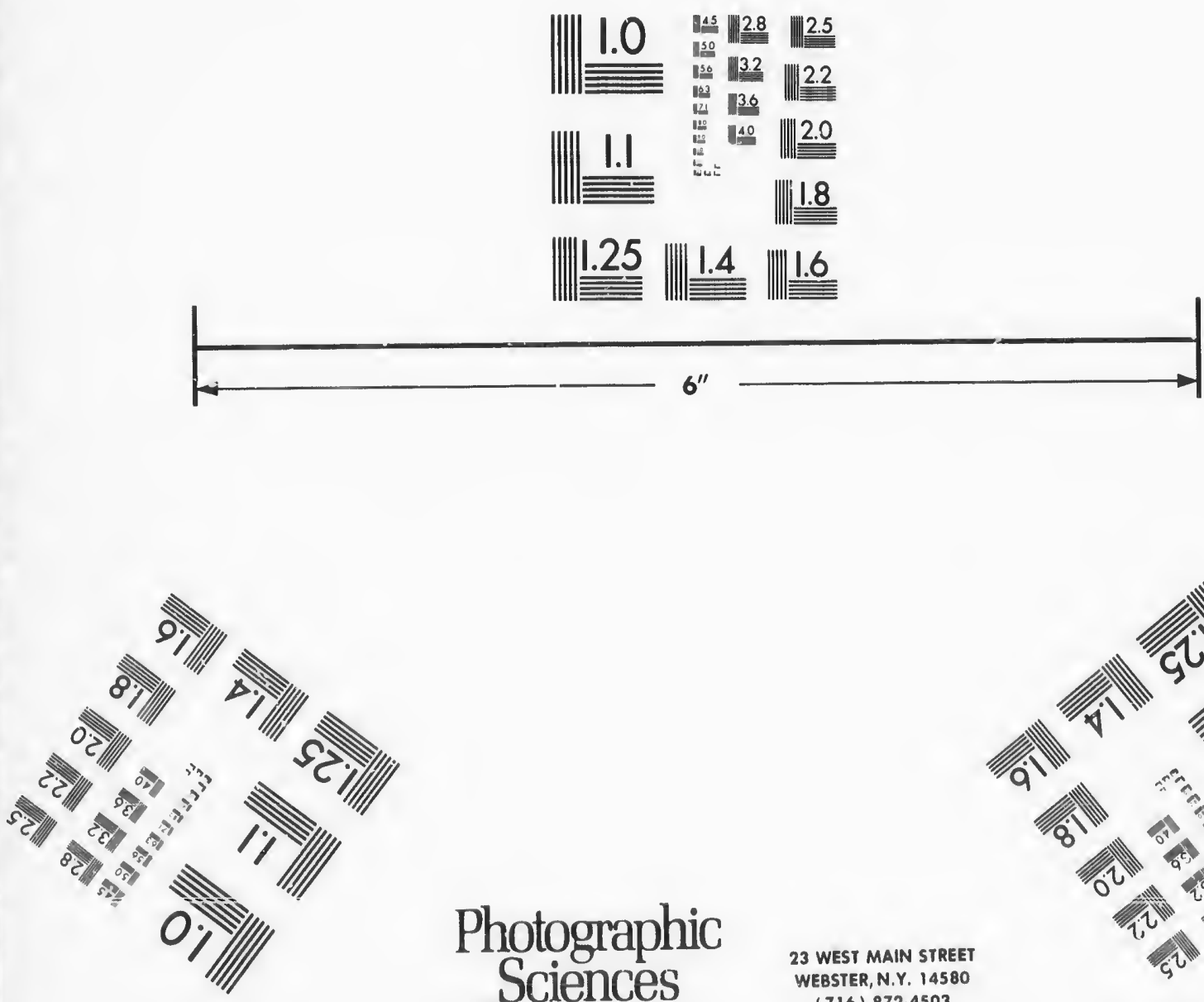

Photographic Sciences Corporation

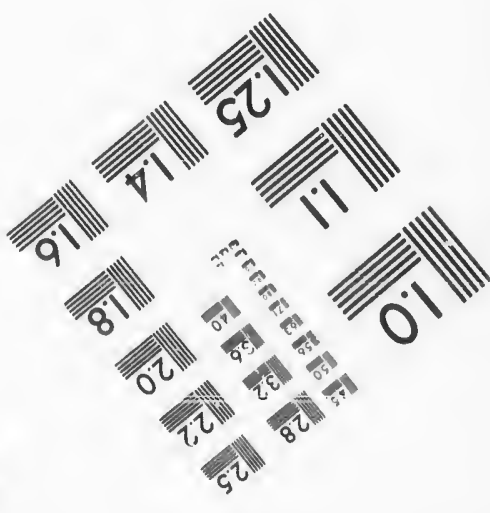




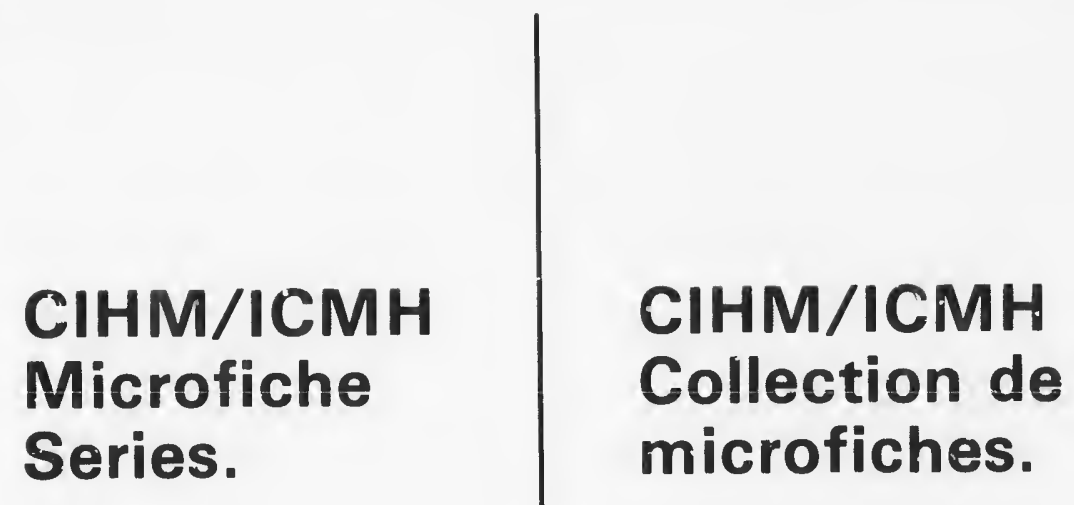

Canadian Institute for Historical Microreproductions / Institut canadien de microreproductions historiques
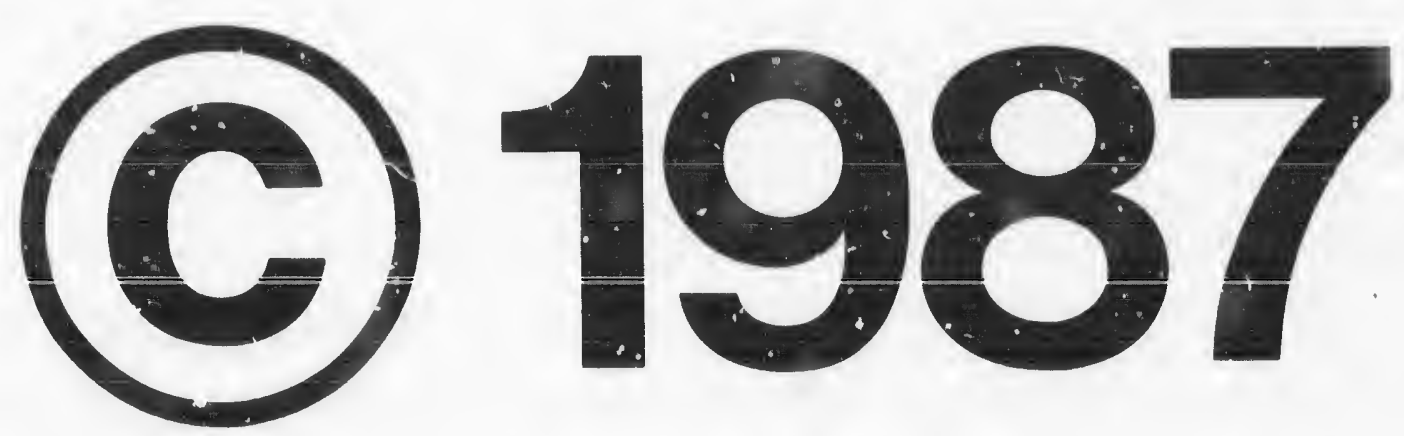
The Institute has attempted to obtain the best original copy available for filming. Featuras of this copy which may be bibliographically unique. which may alter any of the images in the reproduction, or which may significantiy change the usual method of filming, are checked below.

Coloured covers/

Couverture de couleur

Covers damaged/

Couverture endommagé

Covers restored and/or laminated/

Couverture restaurée et/ou pelliculés

Cover title missing/

Le titre de couverture manque

Coloured maps/

Cartes géographiques en souleur

Coloured ink li.e. other than blue or black)/

Encre de couleur (i.e. autre que blese ou noire)

Coloured plates and/or illustrations/

Planches et/ou illustrations en coulour

Bound with other material/

Relie avec d'autres documents

Tight binding may cause shudows or distortion along interior margin/

La reliure serrée peut causer de l'ombrie ou de la distorsion le long de la marge intérieure

Blank leaves added during restoration may appear within the text. Whenever possible, these have been cmitted from filming/

II se peut que certainos pajes blanches ajoutes lors d'une re* tauration apparaissent dans le texte. mais, lorsque cela était possible, ces pages n'ont pas été filmées.

Additional comments:/

Commentaires supplémentaires:
L'Institut a microfilmé le meilleur exemplaire qu'il lui a été possible de se procurer. Les détails de cet exemplaire qui sont peut-étre uniques du point de vue bibliographique, qui peuvent modifier une image reproduite, ou qui peuvent exiger une modification dans la méthode ncrmale de filmage sont indiqués ci-dessous.

Coloured pages/

Pages de couleur

Pages damaged/

Pages endommagées

Pages restored and/or laminated/

Pages restaurées et/ou pelliculées

Peges discoloured, stained or foxed/

Pages décolorées, tachetées ou piquèes

Pages detached/

Pages détachées

Showthrough/

Transparence

Quality of print varies/

Qualité inégale de l'impression

Includes supplementary material/

Comprend du matériel supplémentaire

Only edition available/

Seule édition disponible

Pages wholly or partially obscured by errata slips, tissues, etc., have been refilmed to ensure the best possible image/ Les pages totalemant ou partiellement obscurcies par un favillet d'errata, une pelure. etc.. cnt été filmées à nouveau de façon à obtenir la meilleure image possible.

This itern is filmed at the reduction ratio checked balow/

Ce document est filmé au taux dj réduction indiqué ci-dessous.

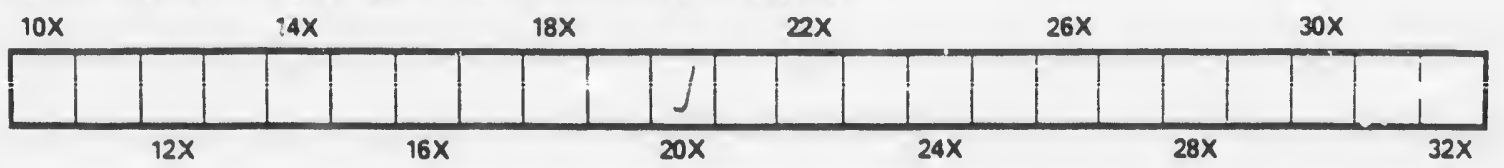


The copy fllmed here has buen reproduced thanks to the generosity of:

\section{Library of Parliament and the} National Library of Canada.

The images appearing here are the best quallty possible considering the condltion arid legibility of the original copy and Ir keepling with the flliming ce 7 tract speciflestions.

Original coples in prinzad paper covers are filmud bugirining with th.e front cover and ending on the last page with a printed or illustrated impreasion, or tha back cover when appropriate. All other original coples are fllmed beginning on the first page with a printed or illustrated impression, and ending on the last page with a printed or illustrated impression.

The last racorded frame on each microfichs shail contain the symbol $\longrightarrow$ Imeaning "CONTINUED \%) or the symbol $\nabla$ (mearing "END"). whichover applies.

Maps, plates, charts, stc., may be fllmed at different reduction ratios. Those too large to be entireiy included in ene exposure are filmed beginning in the uppor loft hand cornor, loft to right and top to bottom, as many frames as required. The following dlagrams illustrete the method:
L'exempluire filmb fut reproduit grâce à la gónórositó de:

\section{La Bibliothdque du Parlement et ia} Bibliotheqque nationaie du Canada.

Les images suivantes ont dt' reproduites avec le plus grand soln, compte tenu de la condition ot de la netteté de l'exemplaire fiimó, ot en conformitó avec les conditions du contrat de filmage.

Lea exempiaires originaux dont la couverture on papler ost Imprimb́a sont flimds en commançant par le premier piat ot en terminant soit par la dernidre page qui comporta una emprointe d'impression ou d'illustration, solt par le secono plat, seion le cas. Tous les autres exempiaires originaux sont filmós en commencant par la prenitdre page qul comporte une ampreinte d'impression ou d'illustration ot en terminant par la dernidre page qui comporte une telle empreinice.

Un des symboles sulvants apparaitra sup la dornitre image de chaque microficha, salon to crs: is symbole $\rightarrow$ signifio "A SUIVRE", io symbole $\nabla$ signifie "FIN".

Les cartes, planches, tableaux, etc., peuvent atre filmb́s à des taux de peduction differents. Lorsque ie dorument est trop grand pour atre reproduit on un seul cilchd, it est filmd a partir de l'angie supdrieur gauche, de gauche a droita. ot de haut on bas, en prenant is nombre d'images nicessalre. Les dlagrammes suivants illustrent ia mothode.
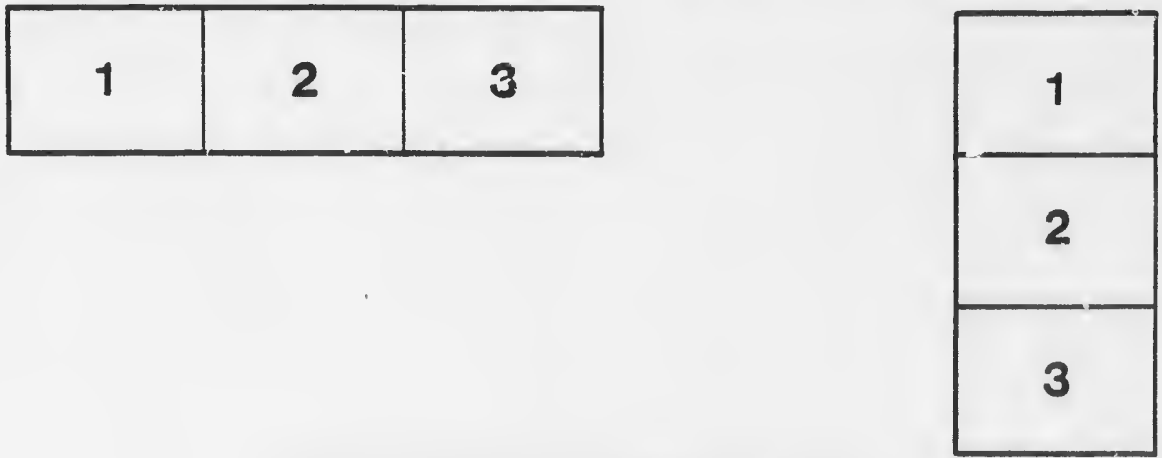

\begin{tabular}{|l|l|l|}
\hline+ & 2 & 3 \\
\hline 4 & 5 & 6 \\
\hline
\end{tabular}


[From tho Canadian Recond of Scinnce, Vol. 1I., No. 2, April, 1886.]

\section{Variation of Water in Trees and Shrubs.}

\section{By D. P. Penhallow.}

The amount of watel wiich highly lignified plants contain, particularly as influenced by season and condition of growth, obviously boars a more or less important relation to physiological processes incident to growth, and most conspicuously to thos 3 which ombrace the movement of sap. Studies relating to the mechanical movement of sap in early spring, at once suggest the question as to how far this is correlated to greater hydration of the tissues at the time when this movement is strongesi. It was with a view to exhibiting this relation more clearly, that determinations of moisture in a large number of woods, representing growth of one and also of two years, collccted at different seasons, wore made by me in $1874 .{ }^{1}$ The range of seasons was not as complete as could have been desired, and no attempt was made ic formulate a ganeral law applicable to this question. With a view to extension of data in this direction, I undertook additional determinations ir. 1882 . The final determinations were made in most cases by Mr. W. E. Stone, then acting as assistant. It is the object of tho present paper to combine all the results thus obtained, together with such other facts

1 W, S, Clark: Agrimulture of Magoachngetto, p. 280. 
as have come to hand, and to see kow far they indicate a general law.

Theoretical considerations lead us to infer that if there is any variation at all, the hydration of the strueture must be greatest during the period of active growth, and least during the period of rest. How far this is supported by the facts, will appear in the rollowing.

\section{IIYDRATION OF DEAD WOOD.}

Incidentally to the maili question, specimens of dead wood, devoid of the bark, and representing an age of four to six or eight years, were collected and the moisture determined. While tho branches were dead, none of them were in advanced stages of decay, so that the eontained water could not be regarded as that of active decomposition, but simply that whieh would be readily retained in the lifeless, air-dried substance as exposed on the tree. The results obtained from fifteen speeies of trees showed an extreme variation of 6.4 per cent., the range being from 12.9 per cent to 19.0 per cent. of water. The mean hydration obtained from these determinations, was 15.1 per cent. The results appear in the following table:-

Hydration of Dead Woods.

Determined at $100^{\circ} \mathrm{C}$.

\begin{tabular}{|c|c|}
\hline SPICIES. & I'ER CENT. WATER. \\
\hline 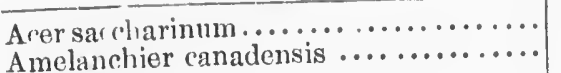 & 18.8 \\
\hline 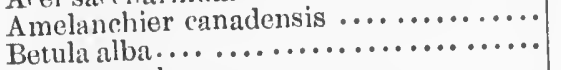 & 19.0 \\
\hline 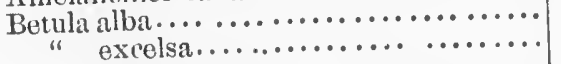 & 15.1 \\
\hline 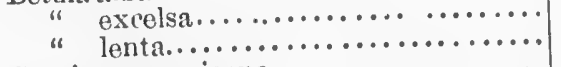 & $\begin{array}{l}15.9 \\
13.7\end{array}$ \\
\hline Carpinus americana $\ldots \ldots \ldots \ldots \ldots \ldots \ldots \ldots$ & 13.8 \\
\hline 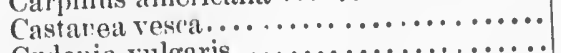 & 14.0 \\
\hline Cydnuia vnlgaris $\ldots \ldots \ldots \ldots \ldots \ldots \ldots$ & 12.9 \\
\hline 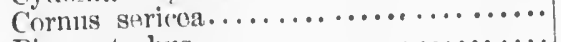 & 13.6 \\
\hline 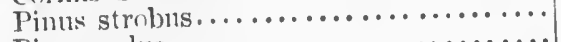 & 11.9 \\
\hline Pirns malus....................... & 12.9 \\
\hline 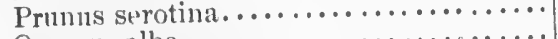 & $\begin{array}{l}17.4 \\
15.5\end{array}$ \\
\hline 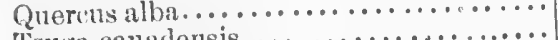 & 18.6 \\
\hline 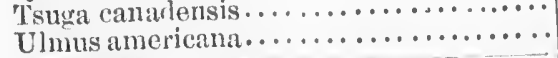 & 13.5 \\
\hline MEAN. & 15.1 \\
\hline
\end{tabular}




\section{HYDRATION OF WOOD FROM LIVING TREES.}

The specimens, upon which the principal facts of this paper are based, wcre collected as soctions of living trees, representing on the one hand, branches of two year's growth, and on the other, branches from two to four years old. For the obvious reason that the bark could not be proporly separated from the wood with any degree of uniformity, it was left on in every case, so that in all the determinations here given, the results show the combined percentage of water in wood and bark. Obviously, this gives a result which ditfer's materially from that which would be obtained if bark and wood were considered separately. Also, while ea: $y$ was taken not to collect specimens in which the dead bark was strongly developed, thus securing as great uniformity as possible, the very fact that the bark was presert, as well as the certainty of its being variahle in structural character and thus also in hydration, as collected even from the same species at different seasons, rendered variations in the results unavoidable. This will doubtless appear upon cxamining individual cases, but the error from this source is reduced in the aggregate, so that the mean results, in vicw of all the precautions taken, may doubiless be accepted as correct.

From an examination of the results that follow, it will appear that, eomparing the younger with the older wood, the percentage of water is sometimes greater in one, sometimes greater in the other, apparently conforming to structural peculiarities of the species. The mean results, however, show clearly what we might infer upon theoretical grounds, viz., that in the youngest growth, as also in the sap wood, the porcentage of water is higher by two per cent. than in the older growtl where the heart-wood is in relative excess. This is found to hold true in the mean results, not only for each season, but also for all seasons; in the former case, however, this difference shows a variation of from 0.8 per cent. to 3.3 per cent. of water. 


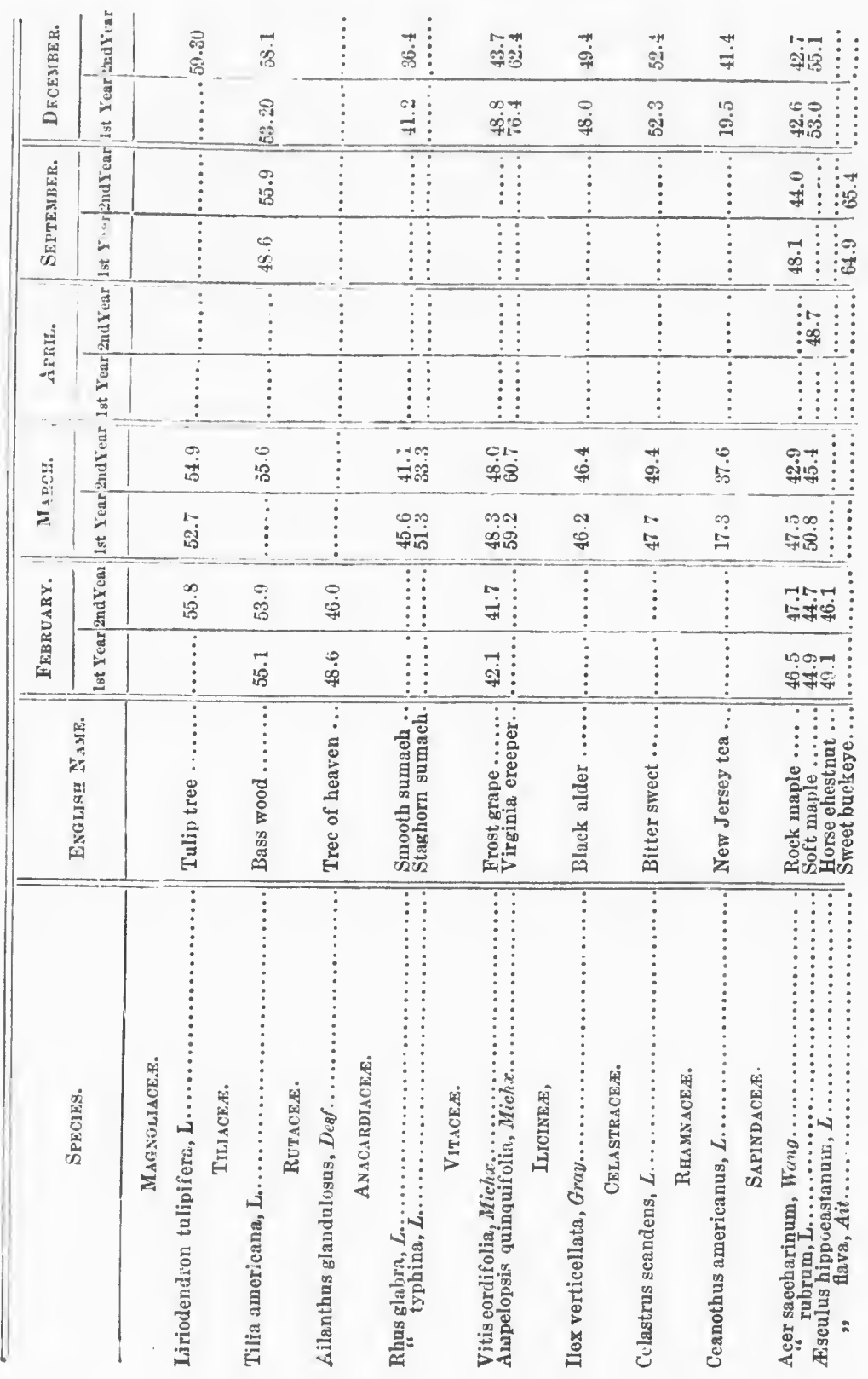




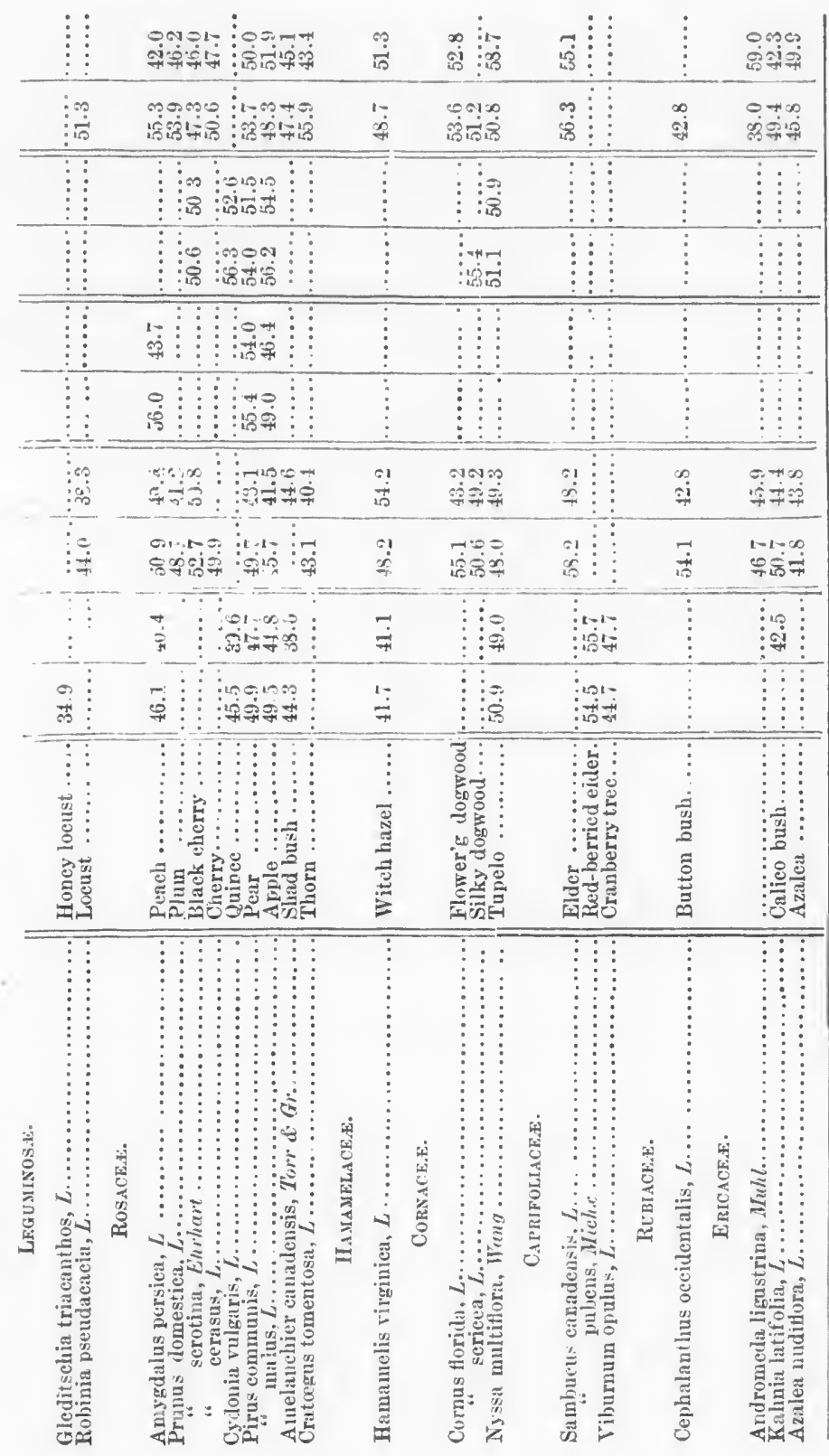


Variation of Water in 'Trees.

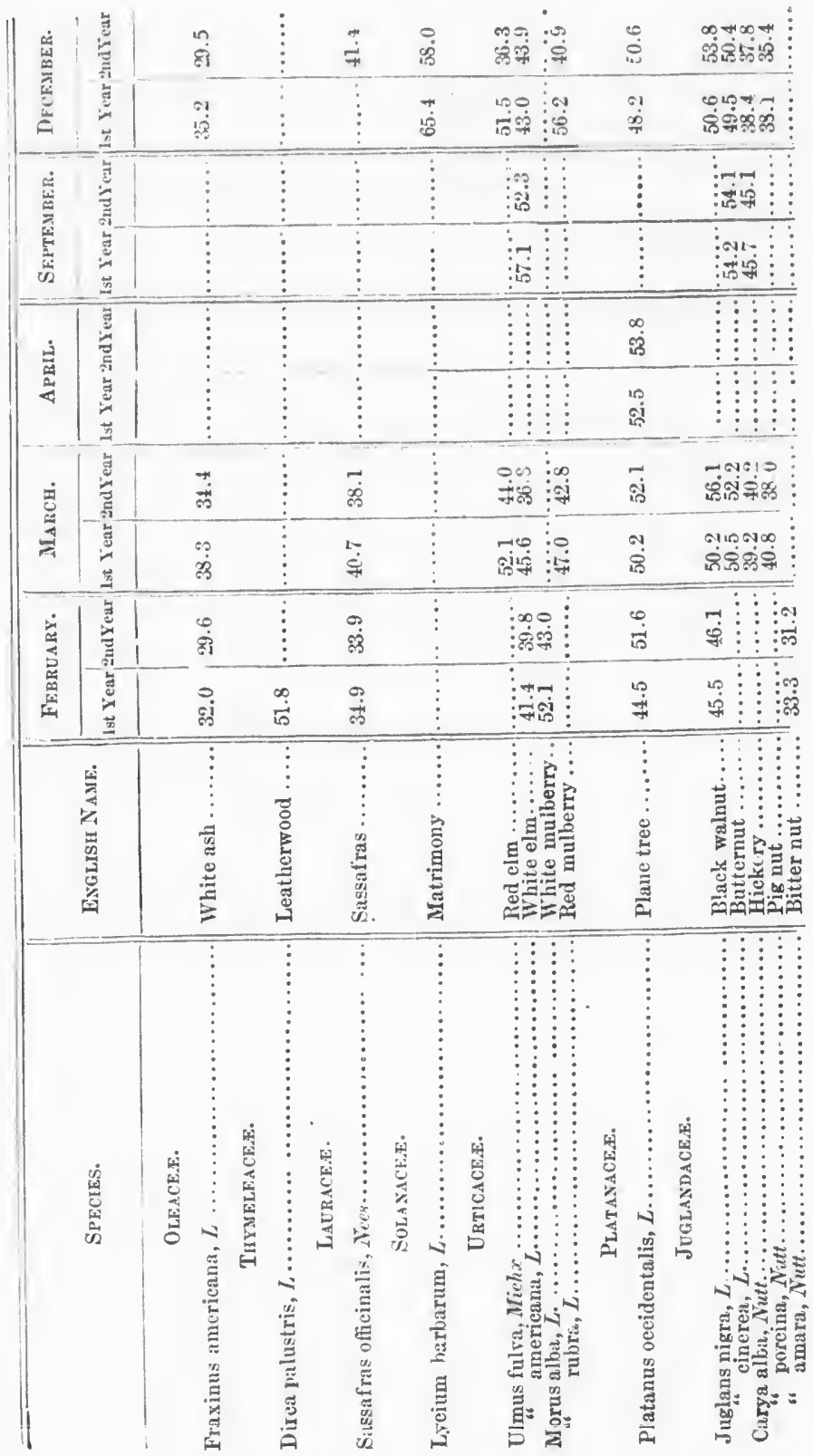


Variation of Water in Tiees.

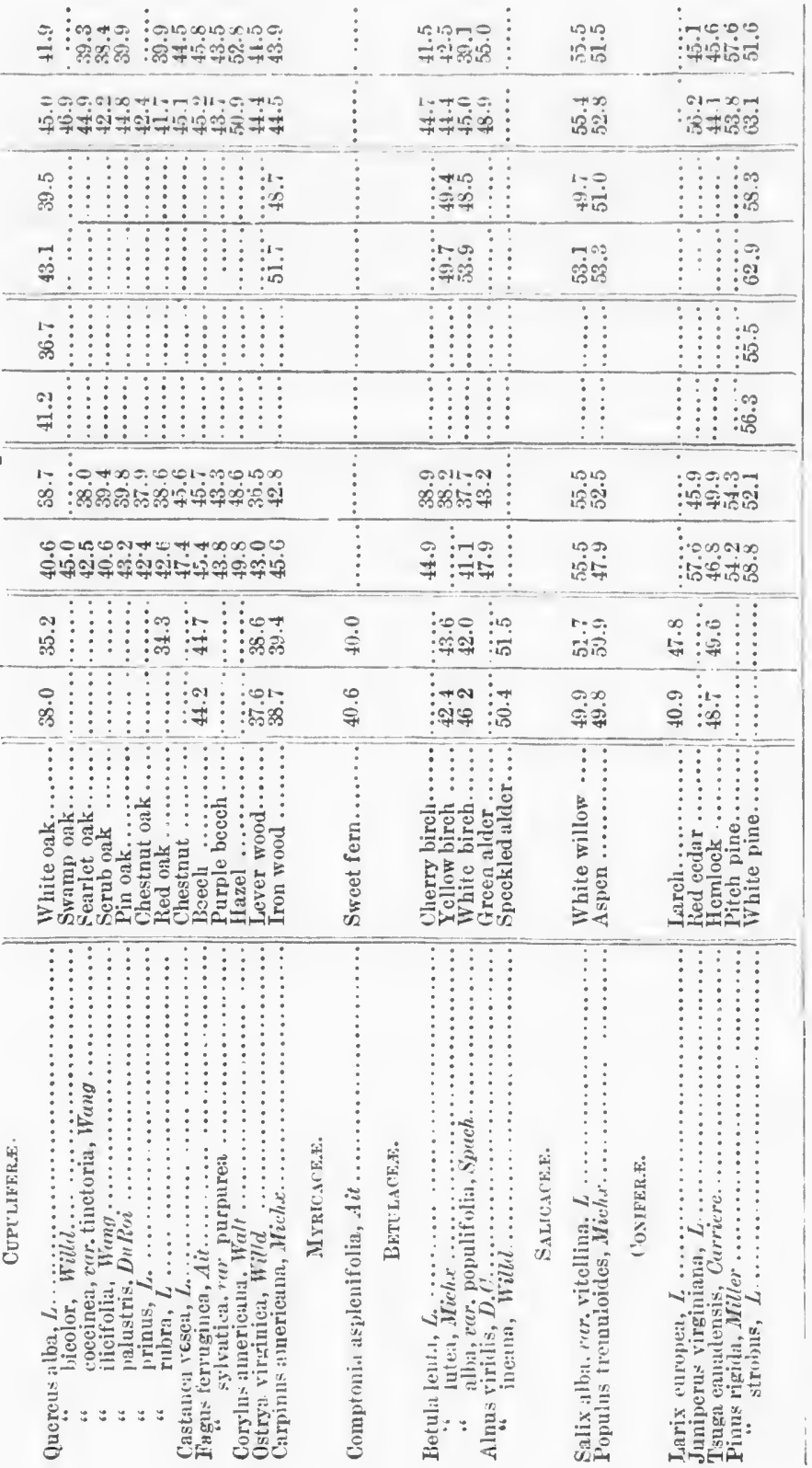


If we next inquiro into the relation whieh seasons bear to the contained water, we shall observe that the percentago rontinually rises firom the midwinter period! until ppring, and that it aguin fulls from the elose of slummer to the midwinter period. 'The extreme variations as exhibited in our' figures, show, between Februiry and September, a difference of $8.4 \mathrm{p}$. e. for the youngest growth, and $7.1 \mathrm{p}$. e. for that whieh is older.

Mean myidation of Wouns.

\begin{tabular}{|c|c|c|c|c|}
\hline \multirow{2}{*}{ Montits. } & \multicolumn{2}{|c|}{ Per Cent. Water. } & \multicolumn{2}{|c|}{ No. for Average. } \\
\hline & 1st Year. & 2nd Yaar. & 1st Year. & 2nd Yoar. \\
\hline 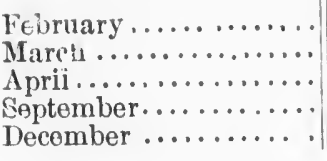 & \begin{tabular}{||l}
44.7 \\
47.2 \\
51.7 \\
53.1 \\
48.3
\end{tabular} & $\begin{array}{l}43.9 \\
44.5 \\
48.4 \\
51.0 \\
47.2\end{array}$ & $\begin{array}{r}37.0 \\
59.0 \\
6.0 \\
19.0 \\
61.0\end{array}$ & $\begin{array}{r}38.0 \\
60.0 \\
7.0 \\
18.0 \\
58.0\end{array}$ \\
\hline Mean.......... & 49.0 & 47.1 & 36.4 & 36.2 \\
\hline
\end{tabular}

Our figures also indieate that the maximum hydration of the tissues must oeeur either in September, 0: at some period intermediate to this month and April. By graphie representation of these results, it will beeome possible to determine with approximate aceuraey the true period at whieh this maximum is reached. The figures show that, fro:n February to April, the rate of pereentage increase is much more rapid than the rate of poreentage deerease from September to Deeember. A curve whieh will show this, should also show the period of maximum pereentage. By reference to the ehart, it will be seen that the eurves for both young and old wood run nearly parallel, but that they tend to apploael at their greatest depression, and to separato more widely at their greatest elevation. It is also seen that, from midwinter to spring, the curve rises rapidly and reaches its greatest slevation about May 18th for the youngest wood, while that for the older wood attains its maximum a few days later, or about the 22 nd. From this 
time on, the curve descends at a more gradual rate until December, when it suddenly diops to its minimum ciepression, which evidently occurs in January.

\section{PERIODS OF OESBATION OF GROW'H.}

As, upon theoretical grounds, the tissues contain most wat3r when the growth is most active, data which will enable us to fix accurately the limiting periods for: the sea son's growth, will have an importunt vearing upon this question. Mr. W. E. Store, ' areepting the completion of terminal buds as marking comnlotion of the longitudinat growti for the entire year, has cained the following data, as establishing periods limiary growth in trees for the latitude of West Point, New York, $41^{\circ} 23^{\prime} \mathrm{N}$. :-

$$
\text { JUTi: } 1 \text { ST. }
$$

Acer saccharinum. Wang.

" rubrum. $L$.

Amolanchier canadensis. Torr \& $Q r$.

Carya alba. Nutt.

Fagus ferruginea. Ait.

Fraxinus americana. $L$.

Hamamelis virginica. $L$.

Kalmia latifolia. $L$.

Populus tremulioides. Sisichx.

Quercus alba. $L$.

$$
\begin{aligned}
& \text { " bicolor. Willd. } \\
& \text { "cccinea. Wang. } \\
& \text { prinus. L. }
\end{aligned}
$$

Sambucus pubens. Michx.

Tilia americana. $L$.

Ulmus americana. $L$.

" fulva. Michx.

$$
\text { JuN: } 15 \mathrm{TH} \text {. }
$$

Bettila lenta. $L$.

Carpinus americana. Michx.

Castanea vesca. $L$.

Juglans nigra. $L$.

Lindera benzoin. Meissner.

Morus rubra. $L$.

Ostrya virginica. Willd.

Prunus cerastus. $L$.

' Bull. Torrey Bot. Club, xii. s, s3. 
JULY $19 \mathrm{TH}$.

Andromeda ligustrina. Muhl.

Alnus incan. Willd.

Nyssa multiflora. Wang.

Staphylea trifolia. $L$.

indeterminate Period.

Ampelopsis quinquifolia. Michx.

Celastrus scandens. $L$.

Rlius. Sp.

Vitis. $S p$.

This, therefore, gives us the following percentage quantities, showing cessation of growth at different periods :-

Nay 1st, commencement of growth.

June 1st, cessation of growth in 51.5 p. c.

June 15th, " " 24.2 "

July 19th, " " " 12.1 "

Indeterminate period " 12.1 "

Growth in length having ceased at these periods, the entrgy of the plant then becomes directed to the lignification of tissues and the deposition of reserve material for growth the following year. These changes, however, involve of necessity, a continual decrease in the contained water. 'The data abore, also, show that the majority of plants coimplete their longitudinal growth within the first six weeks of the growing season; that most of these complete their growth in from three to four weeks; and that, as the season advances, the number of plants still growing rapidly diminishes until the middle of July, after which there are left but few, those being plants like the grape, which continue to grow to the very ond of the season.

A graphic representation of these changes will enable us to institute a comparison with the relations of seasons to hydration of the structure. The lower figure of the chart is the curve expressing this decrease of growth with advancing season. A comparison of both curves will show most conspicuously, that that period, during which growth for 
the season is most rapid is coincident with the period of maximum hydration of the tissues.

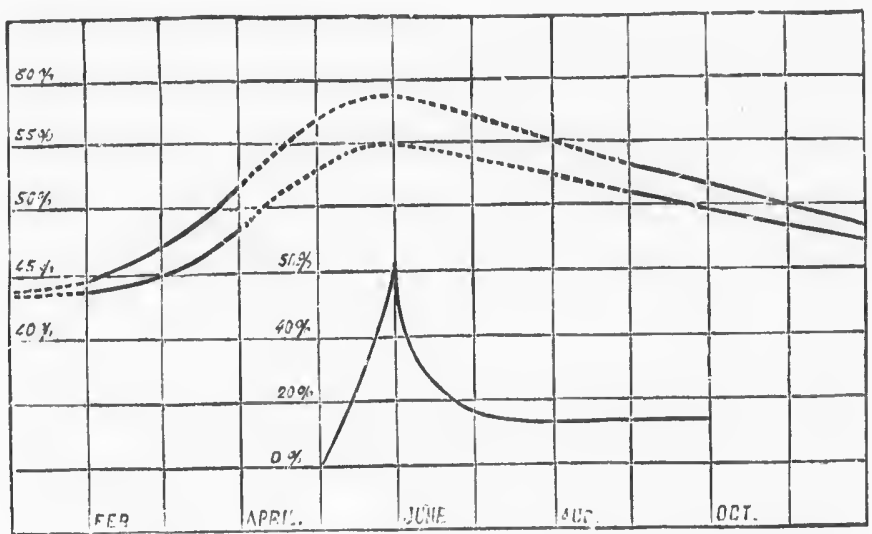

It is cvident from the facts stated, that the amount of water contained in trees can have no direct relation to their bleeding when punctured. Indeed, it is a well-known fact that the bleeding of trees, sucli as enables us to collect maple sugar, is a purely physical proce wholly dependent upon the effect of external temperature in pr.sducing variable internal tension, hence in no sense connucted with physiological processes; that this bleeding may occur at any time during the rest period, provided the conditions of temperature are furorable; hence, that it is most pronounced when there is the least water in the tissues: that during the seasons of most active growth, when the plant contains most water, no bleeding occur's.

\section{CONCLUSIONS.}

From the forcgoing facts, we are justificd in the conclusions which follow:-

(1.) The hydration of woody plants is not constant for' all scasons, and depends upon conditions of growth.

(j.) The hydration renches its maximum during the latter part of May or early June, and its minimum during the month of January. 
(3.) Hydration is greatest in the sap wood; least in the heart wood.

(4.) Greatest hydration is directly correlated to most active growth of the plant,- -lignification, and storage of starcb and other products, being correlated to diminishing hyâration.

These conclusions are to be undere'ood as applying cnly to latstudes lying between New York and Boston. For other latitudes, certain modifications might be necessary. 
